\title{
Review Jurnal Komunikasi Lingkungan
}

Nama :Oktalina

NIM :1920701026

Dosen Pengampu : Dr.,YENRIZAL, S.Sos., M.Si

Mata Kuliah :Komunikasi Lingkungan

Judul Jurnal : Sungai dalam Pemaknaan masyarakat pedesaan studi Etnoekologi Komunikasi pada masyarakat desa Karang Anyar, Banyuasin, Sumatera Selatan

Volume dan Halaman : NIZHAM, VOL. 05, No. 02 Juli-Desember 2016

Tahun :2016

Penulis :Dr.,YENRIZAL, S.Sos., M.Si

Publikasi :Jurnal elektronik Fakultas Ilmu sosial dan Ilmu politik Universitas Islam Negeri Raden Fatah Palembang.

Reviewer :Oktalina (1920701026)

Tanggal : 14 Januari 2021

\section{Latar Belakang :}

Memahami struktur alam memang menjadi kata kunci bagi tertatanya sebuah kehidupan yang stabil dan minim persoalan bencana alam. Hal ini dilakukan dengan sebuah prasyarat bahwa lingkungan dan manusia adalah satu kesatuan yang tidak bisa dipisahkan. Melawan struktur dan tipe alam, tidak akan pernah menguntungkan manusia, karena itu yang terbaik adalah bersahabat atau memahami ritme alam. Ini yang disebut oleh AT Rambo sebagai istilah etnoekologi, atau memandang alam dari sudut pandang manusia yang merupakan satu kesatuan 
tak terpisahkan. Sudut pandang ini bukan dalam konteks antroposentris, tetapi ada kesatuan yang tak terpisahkan.

Sungai memiliki peranan penting untuk menunjang kehidupan manusia. Ketersediaan air yang terdapat pada sungai juga menjadi sumber kehidupan manusia. Sungai yang ekosistemnya terjaga sangat bermanfaat bagi manusia dalam menjalankan aktivitas. Namun sungai di Indonesia sudah banyak yang tercemar. Kementerian Lingkungan Hidup dan Kehutanan menyebutkan 75\% air sungai di Indonesia sudah tercemar berat khususnya oleh limbah domestik (Putranto, 2017).

Kendati berada persis dipinggir sungai, dimana arusnya sering sekali meluap masuk ke wilayah pemukiman penduduk, tetapi tidak pernah dipermasalahkan. Hunian dan aktifitas penduduk tidak terganggu, bahkan menurut keterangan penduduk, dari dulu sampai sekarang tetap seperti itu. Tidak pernah luapan air melebihi batas yang sudah dirasakan selama ini oleh penduduk.

\section{Tujuan :}

Tujuan penelitian yang dilakukan (Yenrizal, penelitian, 2016) ini pada dasarnya ingin membahas masalah tersebut yaitu menekankan pada aspek bagaimana masyarakat memberikan pemaknaan terhadap lingkungan alam yang kemudian memiliki ragam aplikasi di masyakat. Pemaknaan ini ditekankan pada keberadaan Sungai Telang sebagai satu kesatuan hidup yang tak terpisahkan dengan warga sekitar. Bagaimana proses itu terjadi, makna apa yang diberikan dan apa perlakuan yang kemudian dilakukan sebagai bentuk penyesuaian manusia terhadap sungai, itulah fokus penelitian ini.

\section{Metode Penelitian :}

Secara metodologis penelitian ini menggunakan metode kualitatif dengan pendekatan etnoekologi komunikasi. Gagasan etnoekologi komunikasi menggunakan pendekatan yang merupakan penggabungan dari konsep dalam etnoekologi dan etnografi komunikasi. 
Sampel Penelitian : Penduduk Desa Karang Anyar, Banyuasin.

\section{Hasil Penelitian :}

Kajian etnoekologi komunikasi menempatkan bahasan bahwa terdapat beberapa kelompok pemaknaan masyarakat terhadap lingkungan sekitarnya, khusunya sungai. Maknamakna ini lahir dari proses yang berkelanjutan dengan dua faktor utama yaitu, pengalaman sendiri bertahun-tahun, cerita dan pengajaran dari orang tua, serta pengalaman dengan teman sebaya. Beberapa makna tersebut bisa diidentifikasi sebagai berikut.

Pertama, makna terhadap sungai. Bagi masyarakat Karang Anyar sungai adalah urat nadi kehidupan. Disitulah asal mula mereka mendiami wilayah ini, dan disitu pula kehidupan itu disandarkan. Beberapa aktifitas yang mereka lakukan di sungai adalah sarana transportasi utama, mandi, mencuci, sumber air untuk mengairi sawah, mencari ikan dan udang, dan pengatur suhu udara di tanah. Mengenai pengatur suhu udara di tanah ini, diyakini warga karena Sungai Telang punya karakteristik pasang-surut

Kedua, makna terhadap wilayah sempadan sungai. Keterangan dari warga menunjukkan bahwa bibir sungai dianggap sebagai wilayah penting karena disitulah air masuk dan sampahsampah yang ada di sekitar pekarangan akan tertarik ke dalam sungai. Membangun rumah di bibir sungai juga beresiko tinggi karena rawan terhadap abrasi

Ketiga, makna terhadap pemukiman. Pemukiman merupakan areal yang dibangun khusus untuk perumahan warga. Tidak ada rumah yang dibangun arah ke dalam atau jauh dari sungai. Semua rumah posisinya berdekatan dan bahkan bisa dikatakan berderet secara teratur. Bentuk rumah warga juga hampir semuanya adalah model rumah panggung dengan bahan utama dari kayu beratap seng dan sebagian lagi beratapkan daun nipah.

Pengaturan kawasan khusus perumahan sebenarnya tidak dalam bentuk aturan formal. Tujuan utamanya adalah untuk berdekatan dengan sungai sehingga mudah dalam hal transportasi dan akses keluar masuk. Makna penting bagi warga adalah kebersamaan dan interaksi sosial yang lebih dekat. Sementara bentuk rumah panggung adalah bentuk adaptasi masyarakat dengan alam, karena daerah ini bisa dipastikan akan terkena pasang surut air sungai. Mensiasati dengan rumah panggung dianggap solusi yang terbaik. 
Keempat, makna terhadap sumber mata pencaharian. Di Desa Karang Anyar terdapat dua mata pencaharian utama yaitu, bersawah dan mencari ikan. Sawah dianggap mata pencaharian utama, sementara mencari ikan adalah sampingan. Oleh karena itu, dalam konsep masyarakat Karang Anyar, sawah adalah sumber kehidupan yang utama sekali.

Berdasarkan semua penjelasan tentang pemaknaan masyarakat, maka terlihat bahwa semua unsur dalam kehidupan mereka selalu diberi makna tersendiri. Makna ini tidak hanya semata-mata makna simbolik, tetapi diwujudkan dalam bentuk tindakan nyata. Inilah yang dikatakan dalam konteks komunikasi, bahwa simbol melekat pada sebuah benda dan maknanya bersifat sembarang sesuai konteks masyarakat.

Sesuai bahasan di atas, bisa dikatakan bahwa bagi masyarakat Karang Anyar, sungai adalah pusat kehidupan. Sungai tidak saja dimaknai sebagai jalur transportasi, tetapi menjadi urat nadi kehidupan. Semua sistem kehidupan masyarakat memiliki hubungan dengan sungai. Inilah makna terbesar tentang sungai sehingga terwujud pada tipologi masyarakat yang selalu mengikuti dialektika perairan. Secara ringkas bisa dilihat dari bagan berikut.

Makna sungai bagi warga Karang Anyaryaitu sungai bisa dimaknai dalam beragam kegunaan yang bersifat fungsional. Aspek fungsional ini diwariskan dan diteruskan ke berbagai pihak melalui bentuk pengalaman langsung masyarakat sedari kecil hingga dewasa. Anak-anak yang terbiasa mandi di sungai, mencari ikan, bermain, dan sebagainya menjadi sebuah pengalaman tersendiri untuk menyatu dengan sungai. Begitu juga dari kisah-kisah dan ajakan langsung dari orang tua, ikut menjadi pembentuk dan pewaris bagi pengetahuan dan pengalaman generasi berikutnya.

Dalam konteks kajian etnoekologi komunikasi, sisi pemaknaan masyarakat terhadap lingkungan alam setempat, termasuk sungai, merupakan makna yang diberikan sesuia sudut pandang masyarakat. Memaknai artinya memberikan label pada sebuah simbol, dimana label tersebut akan menunjukkan level tertentu dalam masyarakat. Sungai bagi masyarakat Karang Anyar sudah masuk dalam level kosmologi, yaitu sebuah pandangan hidup yang tidak terpisahkan. Setiap aspek kehidupan mereka kemudian terlihat dari bagaimana sungaiberaktifitas. Tidak heran jika dalam banyak kasus, masyarakat selalu mengatakan, "tergantung kondisi sungai". Jika terjadi pasang, maka mereka siap-siap menanam padi, jika 
surut mereka usahakan untuk aktifitas lain. Semua ini adalah bentuk-bentuk pemaknaan yang menjadi aktifitas sehari-hari. (Yenrizal, penelitian, 2016)

\section{Kesimpulan :}

Mengacu pada sudut pandang etnoekologi komunikasi, sungai bagi masyarakat Karang Anyar dimaknai sebagai identitas, batang hari (sumber kehidupan), dan keutuhan kehidupan. Makna ini melekat sejak dari anak sampai orang tua dan kemudian terwujud dalam berbagai rutinitas yang dilakukan. Sudut pandang masyarakat terhadap sungai tersebut tidak terjadi begitu saja, tetapi sebuah proses panjang yang memperlihatkan adanya dialektika pemaknaan terhadap alam semesta. Etnoekologi komunikasi masyarakat Karang Anyar terhadap sungai, menciptakan aspek fungsional kehidupan yang semuanya bersumber dari sungai, terlihat dari berbagai fungsi seperti transportasi, persawahan, perkebunan, perikanan, sempadan, dan pemukiman. (Yenrizal, 2016)

\section{DAFTAR PUSTAKA :}

Yenrizal, Y. (2016). SUNGAI DALAM PEMAKNAAN MASYARAKAT PEDESAAN STUDI ETNOEKOLOGI KOMUNIKASI PADA MASYARAKATDESA KARANG ANYAR, BANYUASIN.Jurnal Nizham Diambil dari http://repository.radenfatah.ac.id/6905/ 